\title{
An in situ hybridization study of the effects of artificial insemination on the localization of cells expressing MHC class II mRNA in the chicken oviduct
}

\author{
W. M. Zheng ${ }^{1}$, M. Nishibori ${ }^{2}$, N. Isobe ${ }^{1}$ and Y. Yoshimura ${ }^{2 *}$ \\ ${ }^{1}$ Graduate School for International Development and Cooperation and ${ }^{2}$ Faculty of Applied \\ Biological Science, Hiroshima University, Higashi-Hiroshima, 739-8528, Japan
}

The aim of this study was to determine the effects of artificial insemination on the localization of antigenpresenting cells expressing MHC class II mRNA in chicken oviducts. Laying hens (35 weeks old) were inseminated with fresh semen or sham-inseminated with saline daily for 3 days. In situ hybridization was performed to detect chicken MHC class II (B-LB21 major gene) mRNA on frozen sections of oviductal infundibulum, uterovaginal junction and vagina by using digoxigenin-labelled PCR probes. Cells expressing MHC class II were observed mainly in the oviductal mucosal stroma and occasionally in the mucosal epithelium. After $24 \mathrm{~h}$, the population of cells expressing MHC class II in the infundibulum was significantly higher in laying hens inseminated with fresh semen than in the control hens sham-inseminated with saline $(P<0.05)$. However, there was no significant difference in the population of cells expressing MHC class II in the uterovaginal junction and vagina between the artificially inseminated and control hens. These results indicate that anti-sperm immune responses, including the influx of cells expressing MHC class II and enhanced MHC class II mRNA expression, probably occur in the infundibulum after artificial insemination.

\section{Introduction}

In hen oviducts, spermatozoa are selected in the vagina and stored for a few weeks in sperm storage tubules located in the uterovaginal junction (Fujii, 1963; Bakst et al., 1994). Fertilization occurs in the infundibulum, which is also the secondary place for sperm storage (Burke, 1984). Recent reports have indicated that there is an increase in the number of leucocytes in the lumen of the vagina shortly after insemination (Higaki et al., 1995) and that phagocytosis of spermatozoa by oviductal cells occurs in the uterovaginal junction (Yoshimura et al., 1997a). In the infundibulum, spermatozoa that do not participate in the fertilization are phagocytosed by macrophages (Koyanagi and Nishiyama, 1981). Van Krey et al. (1987) observed plasma cells in the intercellular spaces in the sperm storage tubule epithelium of infertile hens, and the binding of immunoglobulins with spermatozoa appeared to be the basis for marked loss of sperm viability (Steele and Wishart, 1992). These findings indicate that local immunity in chicken oviducts may affect the fertilizing ability of spermatozoa.

The initial step in the development of an immune response is the presentation of antigens to T lymphocytes by antigen-presenting cells. Antigen-presenting cells expressing major histocompatibility complex $(\mathrm{MHC})$ class II

*Correspondence

Email: yyosimu@hiroshima-u.ac.jp molecules play a central role in the initiation of mucosal immune responses, by presenting antigens to helper $\mathrm{T}$ lymphocytes (Alberts et al., 1994). The chicken MHC contains three major groups of genes, $B-F, B-L$ and $B-G$ that code for class I, class II and class IV molecules, respectively (Pink et al., 1977). The $B-L$ genes encoding MHC class II antigens are classified further into $B-L A$ genes (coding for class II $\alpha$-chain) and $B$-LB genes (coding for class II $\beta$-chain) (Nordskog et al, 1987; Zoorob et al., 1993; Jacob et al., 2000). The $B-L B$ genes are grouped in three families $(B-L B I I$, $B-L B I I I$ and $B-L B V I)$ on the basis of their genetic location and polymorphism, and among these families $B-L B / l$ genes are highly polymorphic (Zoorob et al., 1993; Zheng et al., 1999; Jacob et al., 2000).

In chickens, many cells, such as macrophages, B lymphocytes and activated T lymphocytes, express MHC class II molecules (Nordskog et al., 1987; Vainio et al., 1987), and these cells have been identified in the oviduct by immunocytochemistry (Zheng et al., 1998; Zheng and Yoshimura, 1999). The population of $\mathrm{MHC}$ class $\mathrm{II}^{+}$cells in the chicken oviduct increases during sexual maturation and with ageing (Zheng et al., 1998), and there is a higher frequency of cells positive for MHC class II in the oviducts of laying hens than in moulting hens (Yoshimura et al., 1997b). These findings indicate that physiological status may affect the localization of $\mathrm{MHC}$ class $\mathrm{II}^{+}$cells in chicken oviducts.

If immune responses to spermatozoa occur in the oviduct, it is likely that artificial insemination will enhance 
the expression of MHC class II genes in the infundibulum, uterovaginal junction and vagina, which are the sites of sperm storage and selection. However, no information is available about the localization of cells expressing MHC class II, and whether insemination affects their localization in chicken oviducts. The aim of the present study was to localize cells expressing MHC class II in the oviducts of laying hens and to determine the effects of artificial insemination on their population to provide further evidence that anti-sperm immune responses occur in chicken oviducts.

\section{Materials and Methods}

\section{Treatment of birds and tissue collection}

White Leghorn laying hens (Shaver-strain; Fukuyama Poultry Breeding Farm, Fukuyama) (aged approximately 35 weeks) were kept in individual cages under a light regimen of $14 \mathrm{~h}$ light: $10 \mathrm{~h}$ dark, and provided with feed and water ad libitum. PCR had been used to confirm that the birds contained the specific sequence of $B-L B 21$ major gene as described below. The birds were inseminated intravaginally daily for 3 days with $0.1 \mathrm{ml}$ fresh semen $\left(2 \times 10^{8}\right.$ spermatozoa) collected from White Leghorn males. The control hens were given $0.1 \mathrm{ml}$ saline by the same methods. Five birds were used in each group. The birds were killed by decapitation $24 \mathrm{~h}$ after the final insemination (approximately $6 \mathrm{~h}$ after oviposition). The procedures used were approved by the Research Ethics Committee of Hiroshima University.

The middle part of the infundibulum, uterovaginal junction and vagina of the oviduct and spleen (positive control for MHC class II mRNA expression) were embedded in OCT compound (Miles Inc., Elkhart, IN), snap-frozen in a mixture of isopentane and solid carbon dioxide and stored at $-80^{\circ} \mathrm{C}$ until use. Oviductal and spleen tissues were also collected for the northern blot analysis to confirm the presence of MHC class II mRNA.

\section{Preparation of digoxigenin-labelled DNA probes to chicken MHC class II mRNA}

Amplification of target DNA by PCR. Chicken genomic DNA was isolated from blood cells of laying hens using a nucleic acid isolation kit (SepaGene; Sankojunyaku Co., Tokyo). Two oligonucleotide primers for chicken $B-L B 21$ major gene for $\mathrm{MHC}$ class II were synthesized on the basis of the variable region in the $B$-LB21 major gene (Zoorob et al., 1993). The sequences of the primers were: B-L21U: $5^{\prime}$ TTCTTCTACGGTAAGATAGG-3'; and B-L21L: 5'-CCTGTCCACTTCATTCATTA-3'. PCR was performed in a volume of $50 \mu \mathrm{l}$ containing $0.8 \mu \mathrm{g}$ each primer, $0.0015 \mathrm{~mol} \mathrm{MgCl}_{2}$ $\mathrm{I}^{-1}, 0.0002 \mathrm{~mol}$ each deoxynucleotide (dATP, dCTP, dGTP and dTTP) I-1, $2.5 \cup$ Taq DNA polymerase (Roche Molecular Systems Inc., New Jersey) and approximately 0.2-0.3 $\mu \mathrm{g}$ genomic DNA. Amplification was performed in a Program Temp Control System PC-700 (ASTEC Co.,
TTCTTCTACG GTAAGATAGG TGAGTGCCAC TACCTGAACG 40

GCACCGAGCG GGTGAGGTTT CTGGACAGGC AAATCTACAA 80

CCGGCAGCAG TTCGCGCACT TCGACAGCGA CGTGGGGAAA 120

TTTGTGGCCG ATACACCGCT GGGTGAGCGT CAAGCTGAAT 160

ACTGGAACAG CAACGCCGAG CTTCTGGAGA ACCTAATGAA 200

TGAAGTGGAC AGG

Fig. 1. Sequence of the PCR products of chicken MHC class II $B$ LB21 major gene. The underlined sequences indicate the two primers: B-L21U and B-L21L.

Fukuoka) under the following conditions: $95^{\circ} \mathrm{C}$ for $10 \mathrm{~min}$; then 40 cycles at $95^{\circ} \mathrm{C}$ for $1 \mathrm{~min}$ to denature the double strand DNA, $58^{\circ} \mathrm{C}$ for $1 \mathrm{~min}$ to anneal and $72^{\circ} \mathrm{C}$ for $1 \mathrm{~min}$ to extend; $72^{\circ} \mathrm{C}$ for $10 \mathrm{~min}$ for the final extension. The PCR products were separated by electrophoresis in a $1.5 \%(\mathrm{w} / \mathrm{v})$ agarose gel and the amplified target DNA fragment was recovered using a GenElute ${ }^{\mathrm{TM}}$ agarose spin column (SigmaAldrich Co., St Louis, MO). The nucleotide sequences of the PCR products were determined by Taq dye deoxyterminator cycle sequencing kit (Applied Biosystems, Foster City, CA) using an ABI 310 automated sequencer (Applied Biosystems) and GENETYX-MAC ver 10.1.3 (Software Development Co. Ltd, Tokyo). The sequence of the product is $213 \mathrm{bp}$ in length and corresponds to bp 13-225 of chicken MHC class II B-LBII (Fig. 1) (DDBJ/EMBL/GenBank access number, AJ248585; Jacob et al., 2000).

Preparation of digoxigenin-labelled PCR probes. The purified PCR products were used as template DNA in a repeated PCR (same cycling conditions as described above) using a PCR-digoxigenin (DIG) probe synthesis kit (Roche Molecular Biochemicals, Mannheim). The PCR probes were precipitated by ethanol and suspended in $50 \mu \mathrm{l} \mathrm{TE}$ buffer (0.01 mol Tris- $\mathrm{HCl} \mathrm{I}^{-1}, 0.001$ mol EDTA I-1, $\mathrm{pH} 7.4$ ).

Northern blot analysis. Total RNA was extracted from the spleen and mucosal tissues of oviductal infundibulum, uterovaginal junction and vagina of laying hens using ISOGEN-LS (Nippon Gene Co., Toyama). The denatured RNA samples (5 $\mu \mathrm{g}$ per lane) were subjected to electrophoresis through a $1.0 \%(\mathrm{w} / \mathrm{v})$ agarose gel and transferred to a nylon membrane (Hybond $\mathrm{N}^{+}$; Amersham, Little Chalfont) overnight using $20 \times$ SSC $(1 \times$ SSC solution consisted of 0.15 mol sodium chloride $\mathrm{I}^{-1}$ and $0.015 \mathrm{~mol}$ trisodium citrate $\mathrm{I}^{-1}$ ) as transfer buffer. After fixation the membrane was incubated at $50^{\circ} \mathrm{C}$ for $3 \mathrm{~h}$ in prehybridization solution $(50 \% \quad(\mathrm{v} / \mathrm{v})$ deionized formamide, $5 \times \mathrm{SSC}, 2 \%(\mathrm{w} / \mathrm{v})$ blocking reagent (Roche Molecular Biochemicals), $0.1 \%$ (w/v) N-laurylsarcosine, $0.02 \%(w / v)$ SDS). Hybridization was carried out at $50^{\circ} \mathrm{C}$ overnight in $10 \mathrm{ml}$ prehybridization solution containing $50 \mu \mathrm{l}(0.7-1.0 \mu \mathrm{g})$ DIG-labelled PCR probes, which were denatured at $85^{\circ} \mathrm{C}$ before use. After 

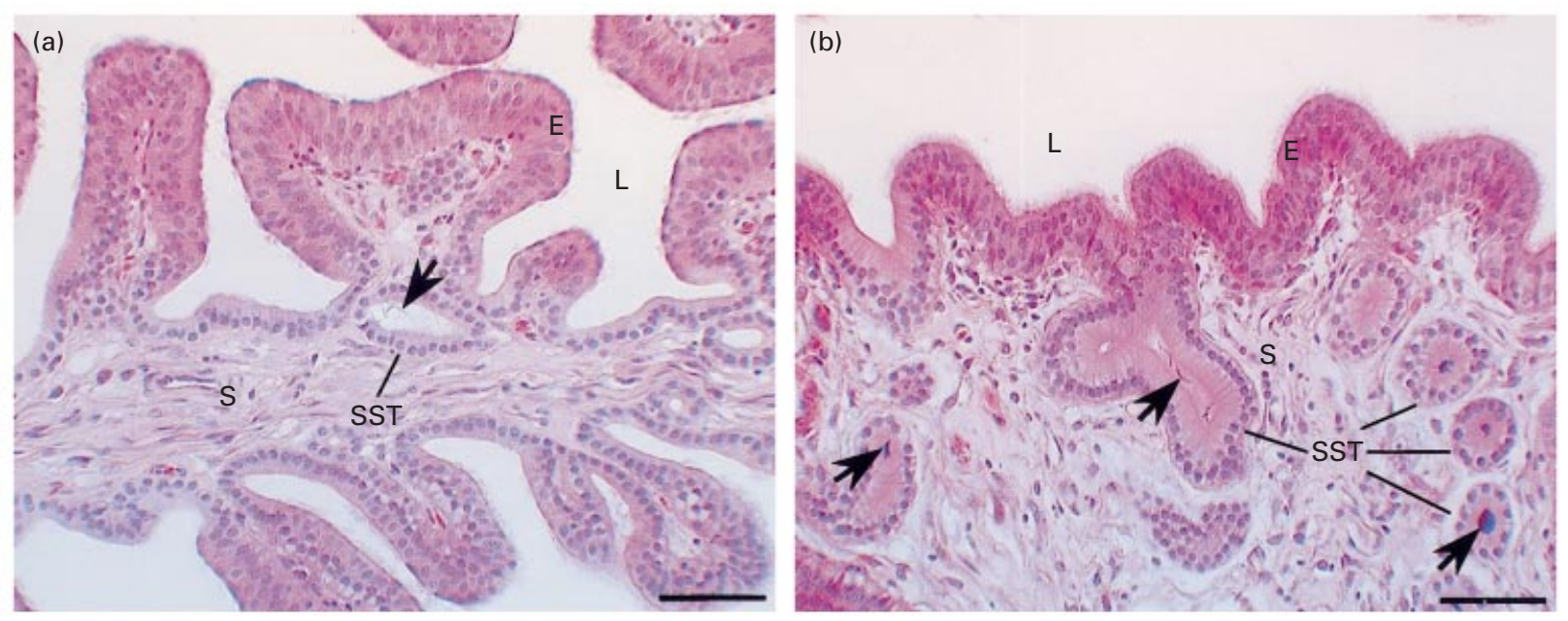

Fig. 2. Sections of (a) oviductal infundibulum and (b) uterovaginal junction of artificially inseminated laying hens. Arrows indicate the presence of spermatozoa in the sperm storage tubules (SST). E: mucosal epithelium; L: lumen of the oviduct; S: mucosal stroma. Haematoxylin and eosin staining. Scale bars represent $50 \mu \mathrm{m}$.

hybridization, the membrane was washed in $2 \times$ SSC, $0.1 \%$ $(\mathrm{w} / \mathrm{v}) \mathrm{SDS}$ at room temperature $(2 \times 10 \mathrm{~min})$, and then in $0.2 \times$ SSC, $0.1 \%(\mathrm{w} / \mathrm{v}) \mathrm{SDS}$ at $55^{\circ} \mathrm{C}(2 \times 10 \mathrm{~min})$. The hybridized products were detected immunologically by incubating the membrane with anti-DIG antibody conjugated with alkaline phosphatase (diluted to $1: 5000$ in $1 \%(\mathrm{w} / \mathrm{v})$ blocking reagent) (Roche Molecular Biochemicals) and CDP-Star chemiluminescent substrate (New England Biolabs Inc., Beverly, MA), and exposing it to X-ray film.

\section{In situ hybridization for MHC class II mRNA}

Cryostat sections (6 $\mu \mathrm{m}$ thickness) were air-dried on slides pretreated with 3-aminopropyl triethoxysilane. Sections were fixed with $4 \%(\mathrm{w} / \mathrm{v})$ paraformaldehyde in PBS, pH 6.8, for 10 min, incubated in PBS containing $0.1 \%$ (v/v) diethylpyrocarbonate (Katayama Chem., Osaka) for $15 \mathrm{~min}$, and washed in PBS for $5 \mathrm{~min}$. The sections were treated with $2 \mu \mathrm{g}$ proteinase $\mathrm{K} \mathrm{ml}^{-1}$ (Merck, Darmstadt) in $0.1 \mathrm{~mol}^{\text {Tris- }} \mathrm{HCl} \mathrm{I}{ }^{-1}$ and $0.05 \mathrm{~mol}^{\mathrm{EDTA} \mathrm{I}}{ }^{-1}, \mathrm{pH} 8.0$ at room temperature for $15 \mathrm{~min}$. The sections were washed in PBS for $5 \mathrm{~min}$ and then fixed again in $4 \%(\mathrm{w} / \mathrm{v})$ paraformaldehyde for $10 \mathrm{~min}$ and washed in PBS for $5 \mathrm{~min}$. The slides were immersed in $0.1 \mathrm{~mol}$ triethanolamine $\mathrm{I}^{-1}, \mathrm{pH} 8.0$, containing $0.25 \%(\mathrm{v} / \mathrm{v})$ acetic anhydride for $20 \mathrm{~min}$. The slides were washed twice in PBS (10 min each), and dehydrated through successive baths of ethanol $(70,95$ and $100 \%(\mathrm{v} / \mathrm{v}))$ and air-dried. The sections were rehydrated through successive baths of ethanol $(100,95$ and $70 \%(\mathrm{v} / \mathrm{v}))$ and PBS. The sections were incubated for $30 \mathrm{~min}$ at $37^{\circ} \mathrm{C}$ in a prehybridization solution $(30 \mu \mathrm{l}$ of $100 \%$ deionized formamide, $20 \mu \mathrm{l}$ of $20 \times$ SSC, $20 \mu \mathrm{l}$ TE buffer, $10 \mu \mathrm{l}$ denatured salmon sperm DNA $\left(10 \mathrm{mg} \mathrm{ml}^{-1}\right), 10 \mu \mathrm{l}$ tRNA $\left(10 \mathrm{mg} \mathrm{ml}^{-1}\right)$ and $10 \mu \mathrm{l} \mathrm{H}_{2} \mathrm{O}$ ). The sections were hybridized with probe at $42^{\circ} \mathrm{C}$ for $10 \mathrm{~min}$ and at $37^{\circ} \mathrm{C}$ for $16 \mathrm{~h}$. The hybridization solution consisted of $10 \mu \mathrm{l}(0.15-0.2 \mu \mathrm{g})$ DIG-labelled PCR probes and $500 \mu \mathrm{l}$ prehybridization solution.

After hybridization, the slides were washed with 30\% $(\mathrm{v} / \mathrm{v})$ formamide in $2 \times \mathrm{SSC}(2 \times 20 \mathrm{~min})$ and PBS containing $0.05 \%(\mathrm{v} / \mathrm{v})$ Tween-20 $(20 \mathrm{~min})$ at $42^{\circ} \mathrm{C}$. Sections were equilibrated with buffer I $\left(0.1 \mathrm{~mol}^{\text {Tris I }} \mathrm{I}^{-1}, 0.15 \mathrm{~mol}\right.$

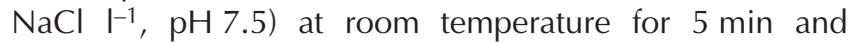
incubated at room temperature for 30 min with $5 \%(\mathrm{w} / \mathrm{v})$ blocking reagent (Boehringer Mannheim $\mathrm{GmbH}$ ) and 0.001 mol levamisole hydrochloride $\mathrm{I}^{-1}$ (Nacalai Tesque, Kyoto) in buffer $\mathrm{I}$. The slides were incubated in a humidified chamber overnight at $4^{\circ} \mathrm{C}$ with sheep anti-DIG antibody conjugated with alkaline phosphatase (Boehringer Mannheim $\mathrm{GmbH}$ ) diluted to $1: 250$ in buffer I containing $1 \%(\mathrm{w} / \mathrm{v})$ blocking reagent and $0.001 \mathrm{~mol}$ levamisole hydrochloride $\mathrm{I}^{-1}$. After washing with buffer I $(2 \times 20 \mathrm{~min}$ at room temperature), the slides were washed with buffer II $\left(0.1 \mathrm{~mol}_{\text {Tris }} \mathrm{I}^{-1}, 0.05 \mathrm{~mol}\right.$ $\mathrm{MgCl}_{2} \mathrm{I}^{-1}, 0.1 \mathrm{~mol} \mathrm{NaCl} \mathrm{I-1}, \mathrm{pH}$ 9.5) for $5 \mathrm{~min}$ at room temperature. The slides were incubated for $6-8 \mathrm{~h}$ at room temperature with alkaline phosphatase substrate mixture consisting of $0.35 \mathrm{mg}$ nitro blue tetrazolium $\mathrm{ml}^{-1}$ (Nacalai Tesque) and $0.175 \mathrm{mg}$ 5-bromo-4-chloro-3-indolylphosphate p-toluidine salt $\mathrm{ml}^{-1}$ (Nacalai Tesque) in buffer II. After colour development the slides were washed in TE buffer and covered with $50 \%(\mathrm{v} / \mathrm{v})$ glycerol.

A negative control was prepared by omitting the DIGlabelled PCR probes in the hybridization solution.

\section{Observations and analysis of data}

Sections were examined under a light microscope. The population of cells expressing MHC class II mRNA was analysed by an image analysis computer system, MacAspect (Mitani Co., Fukui). Two different areas (each approximately $15000-30000 \mu \mathrm{m}^{2}$ ) in the subepithelial 

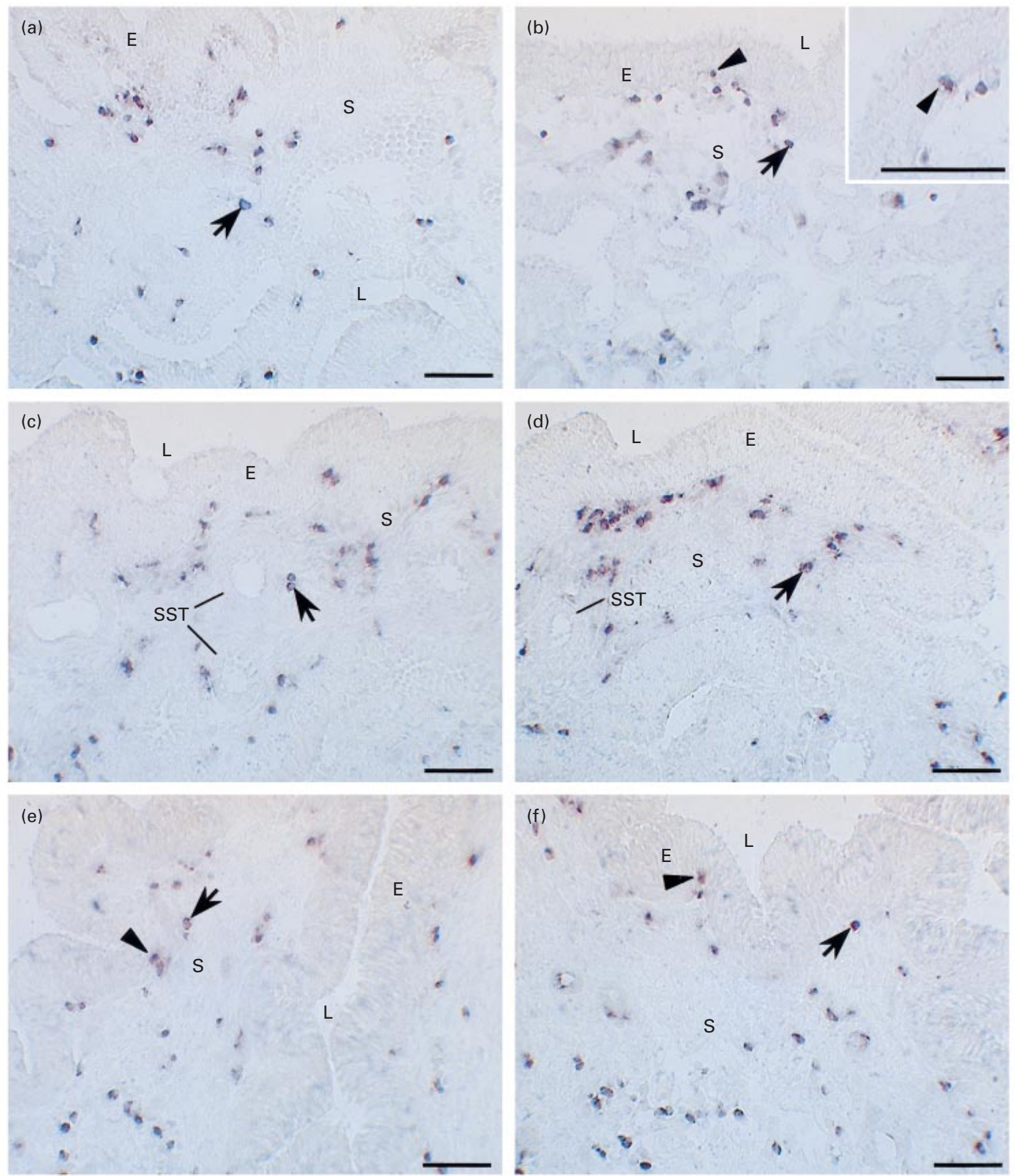

Fig. 3. Oviductal sections of laying hens hybridized with digoxigenin-labelled PCR probes for detection of cells expressing MHC class II. Arrows and arrowheads indicate examples of cells expressing MHC class II in the stroma and epithelium, respectively. mRNA-expressing cells are observed mainly in the mucosal stroma. (a) and (b) are infundibulum of an artificially inseminated hen and a control hen, respectively. The inset of (b) shows a magnified view of the MHC class II mRNA-expressing cell in the mucosal epithelium. (c) and (d) are uterovaginal junction of an artificially inseminated hen and a control hen, respectively. (e) and (f) are vagina of an artificially inseminated hen and a control hen, respectively. E: mucosal epithelium; S: mucosal stroma; L: lumen of the oviduct; SST: sperm storage tubules. Scale bars represent $50 \mu \mathrm{m}$. 


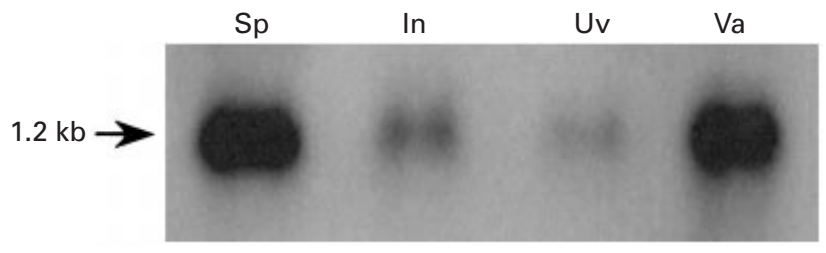

Fig. 4. Northern blot for MHC class II (B-LB21 major gene) mRNA in the oviductal mucosal tissues and spleen of a chicken. Total RNA $(5 \mu \mathrm{g})$ was subjected to electrophoresis through a $1.0 \%(\mathrm{w} / \mathrm{v})$ agarose gel, transferred to a nylon membrane, hybridized with digoxigenin (DIG)-labelled PCR probes and detected by anti-DIG antibody conjugated with alkaline phosphatase and CDP-Star chemiluminescent substrate. The membrane was exposed to X-ray film. The molecular size of the RNA was confirmed to be $1.2 \mathrm{~kb}$. Sp: spleen (positive control); In: infundibulum; Uv: uterovaginal junction; Va: vagina.

stroma were examined in each section. The mean of the two counts was calculated and expressed as the cell number in $10000 \mu \mathrm{m}^{2}$. The significance of difference in the number of cells between the artificially inseminated and control hens or among oviductal segments was examined by Student's $t$ test or one-way ANOVA followed by Duncan's multiple $t$ test. $P<0.05$ was considered significant.

\section{Results}

The mucosal tissue of the oviduct consisted of the mucosal epithelium and stroma. Spermatozoa were observed in the sperm storage tubules located in the stroma in both the uterovaginal junction and infundibulum of the inseminated laying hens (Fig. 2). Cells expressing MHC class II were present in all sections from the infundibulum, uterovaginal junction and vagina of the inseminated and control laying hens. These cells were dispersed throughout the mucosal stroma and were also observed occasionally in the mucosal epithelium (Fig. 3). No obvious accumulation of cells expressing MHC class II was observed in or around the sperm storage tubules of the inseminated hens (Fig. 3). Cells expressing MHC class II were also observed in spleen sections, which were used as positive controls, but not in negative control sections that were prepared by omitting PCR probes from the hybridization solution (data not shown). Northern hybridization confirmed the expression of MHC class II mRNA in the spleen, infundibulum, uterovaginal junction and vagina (Fig. 4). The molecular size of the RNA was $1.2 \mathrm{~kb}$.

The population of cells expressing MHC class II was significantly higher in the infundibulum of hens at $24 \mathrm{~h}$ after artificial insemination compared with that of control hens $(P<0.05)$, but no significant effects were observed in the uterovaginal junction and vagina. In the inseminated laying hens, the population of cells expressing MHC class II in the infundibulum was significantly greater than that in the uterovaginal junction and vagina $(P<0.05)$ (Fig. 5).

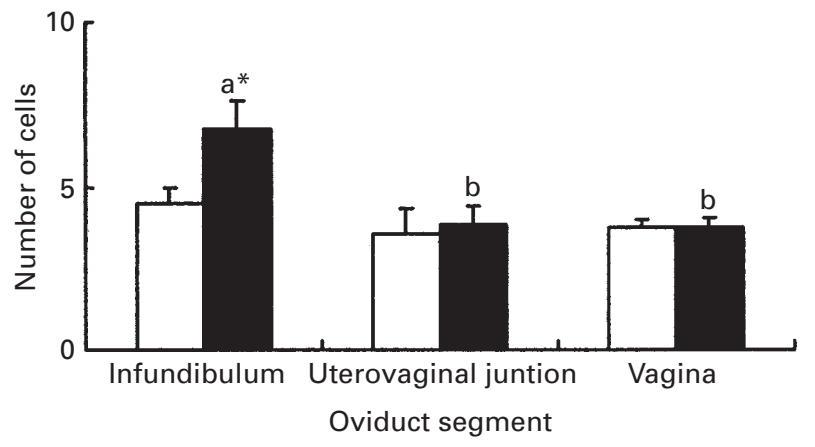

Fig. 5. Frequency of cells expressing MHC class II in the subepithelial stroma of the oviduct in laying hens inseminated with fresh semen ( $\square$ ) or saline solution ( $\square$; control). Each bar represents the mean $\pm \operatorname{SEM}(n=5)$ of the number of positive cells in $1 \times 10^{4}$ $\mu \mathrm{m}^{2}$ tissue. ${ }^{*}$ Indicates that the value is significantly different from the corresponding control value $(P<0.05)$. abDifferent superscripts indicate significant differences among oviductal segments in the artificial insemination group $(P<0.05)$.

\section{Discussion}

The significant findings of this study are: (i) cells expressing MHC class II were present in the mucosal tissues of the chicken oviduct; and (ii) artificial insemination of hens increased the population of cells expressing MHC class II in the oviductal infundibulum at $24 \mathrm{~h}$ after treatment.

This is believed to be the first report that shows the expression of MHC class II mRNA in chicken oviducts. Northern blot analysis showed that the infundibulum, uterovaginal junction and vagina contained MHC class II mRNA. In situ hybridization revealed that cells expressing MHC class II were present in the mucosal stroma and epithelium of laying hens. These results indicate that antigen-presenting cells synthesizing MHC class II molecules are distributed throughout the oviductal mucosa. The presence of cells expressing MHC class II in the oviductal mucosal tissue indicates that the mucosal tissues of the infundibulum, uterovaginal junction and vagina are probably the inductive sites of immune responses to antigens that may come into contact with or invade the mucosal epithelium. These cells may present antigens to helper T cells to initiate a local immune response.

The sperm storage tubules in the uterovaginal junction were full at day 1 after insemination in laying hens (Brillard, 1993). In the present study, artificial insemination significantly increased the population of cells expressing MHC class II in the infundibulum, but not in the uterovaginal junction and vagina, indicating that anti-sperm immune responses possibly occurred more strongly in the infundibulum than in the uterovaginal junction and vagina $24 \mathrm{~h}$ after insemination. The reason why no significant effects were observed in the uterovaginal junction and vagina in response to insemination is not known. It is assumed that in the infundibulum immune responses to 
spermatozoa occur even after $24 \mathrm{~h}$ of insemination, whereas in the vagina and uterovaginal junction the population of cells expressing MHC class II may not be increased greatly or the increased size of the population may return to pre-insemination values by $24 \mathrm{~h}$ after insemination. A greater population of cells expressing $\mathrm{MHC}$ class II may be kept for longer in the infundibulum because spermatozoa that did not participate in fertilization were phagocytosed by macrophages (Koyanagi and Nishiyama, 1981) and macrophages are one of the cell types that express MHC class II. Furthermore, it is likely that spermatozoa are protected from immune response through storage within the sperm storage tubule in the uterovaginal junction, as no obvious accumulation or increase of MHC class II mRNA expression was observed in or around sperm storage tubules.

In conclusion, the presence of cells expressing $\mathrm{MHC}$ class II in oviducts of hens indicates that MHC class II antigens are synthesized locally in the oviducts. Anti-sperm immune responses, including the influx of cells expressing $\mathrm{MHC}$ class II or enhanced MHC class II mRNA expression, probably occur in the oviductal infundibulum $24 \mathrm{~h}$ after insemination with semen.

This work was supported by a Grant-in-Aid for Scientific Research (C) from the Ministry of Education, Science, Sports and Culture of Japan to Y. Yoshimura.

\section{References}

Alberts B, Bray D, Lewis J, Raff M, Roberts K and Watson D (1994) The immune system. In Molecular Biology of the Cell pp 1228-1251 Eds M Robertson and R Adams. Garland Publishing Inc., New York

Bakst MR, Wishart G and Brillard JP (1994) Oviducal sperm selection, transport, and storage in poultry Poultry Science Review 5 117-143

Brillard JP (1993) Sperm storage and transport following natural mating and artificial insemination Poultry Science 72 923-928

Burke WH (1984) Avian reproduction. In Duke's Physiology of Domestic Animals pp 847-862 Ed. MJ Swenson. Comstock Publishing Associates, a division of Cornell University Press, Ithaca and London

Fujii S (1963) Histological and histochemical studies on the oviduct of the domestic fowl with special reference to the region of uterovaginal juncture Archivum Histologicum Japonicum 23 447-459

Higaki K, Yoshimura Y, Tamura T and Okamoto T (1995) Localization of spermatozoa and leukocytes in vagina and uterovaginal junction after copulation in Japanese quail (Coturnix coturnix japonica). Japanese Poultry Science 32 387-393

Jacob JP, Milne S, Beck S and Kaufman J (2000) The major and minor class II $\beta$-chain $(B-L B)$ gene flank the Tapasin gene in the $B-F / B-L$ region of the chicken major histocompatibility complex Immunogenetics $\mathbf{5 1}$ 138-147

Koyanagi F and Nishiyama $\mathbf{H}$ (1981) Fate of spermatozoa that do not participate in fertilization in the domestic fowl Cell and Tissue Research 214 89-95

Nordskog AW, Pevzner IY and Lamont SJ (1987) Subregions and functions of the chicken major histocompatibility complex Poultry Science $\mathbf{6 6}$ 790-794

Pink JRL, Droege W, Hala K, Miggiano VC and Ziegler A (1977) A threelocus model for the chicken major histocompatibility complex Immunogenetics 5 203-216

Steele MG and Wishart GJ (1992) Evidence for a species-specific barrier to sperm transport within the vagina of the chicken hen Theriogenology 38 1107-1114

Vainio O, Toivanen P and Toivanen A (1987) Major histocompatibility complex and cell cooperation Poultry Science 66 795-801

Van Krey HP, Schuppin GT, Denbow DM and Hulet RM (1987) Turkey breeder hen infertility associated with plasma cells in the uterovaginal sperm storage glands Theriogenology 27 913-921

Yoshimura Y, Higaki K and Tamura T (1997a) Phagocytosis of sperm by the oviductal mucosa in Japanese quail Coturnix coturnix japonica. Assisted Reproductive Technology/Andrology 9 213-222

Yoshimura Y, Okamoto T and Tamura T (1997b) Localization of MHC class II, lymphocytes and immunoglobulins in the oviduct of laying and moulting hens British Poultry Science 38 590-596

Zheng WM and Yoshimura Y (1999) Localization of macrophages in the chicken oviduct: effects of age and gonadal steroids Poultry Science $\mathbf{7 8}$ 1014-1018

Zheng WM, Yoshimura Y and Tamura T (1998) Effects of age and gonadal steroids on the localization of antigen-presenting cells, and $\mathrm{T}$ and $\mathrm{B}$ cells in the chicken oviduct Journal of Reproduction and Fertility 114 45-54

Zheng D, O'Keefe G, Li L, Johnson LW and Ewald SJ (1999) A PCR method for typing $B-L \beta / /$ family (class II MHC) alleles in broiler chickens Animal Genetics 30 109-119

Zoorob R, Bernot A, Renoir DM, Choukri F and Auffray C (1993) Chicken major histocompatibility complex class II $B$ genes: analysis of interallelic and interlocus sequence variance European Journal of Immunology 23 1139-1145

Received 16 February 2001.

First decision 12 April 2001.

First revision received 11 June 2001.

Accepted 14 June 2001. 